\title{
A Bee-hive Fungus, Pericystis alvei, Gen. et Sp. Nov.
}

\author{
BY
}

ANNIE D. BETTS, B.Sc.

\section{With Plates LXXV and LXXVI.}

THE bee-hive Fungi, as a class, have been studied but little, though bee-keepers have long been aware of the occurrence of 'mould' in their hives, and some of the diseases to which the honey bee is liable are known to be of a fungous nature. An investigation was begun with the object of filling this gap in our knowledge of the economy of the hive ; in the course of it, the species which is the subject of the present paper was met with.

Pericystis alvei is a common fungus, being in fact the principal constituent of the 'pollen-mould' prevalent in hives during the winter and early spring. It grows, as this name indicates, on the pollen stored in the combs (P1. LXXVI, Fig. I I), and is not found, so far as is known, on any other substratum. The contents of cells attacked by the fungus tend to dry up ultimately into hard plugs, which often split into layers (see Pl. LXXVI, Fig. I2) ; they are permeated by mycelium, which is, however, most plentiful on the surfaces and especially on the top (that is, the surface exposed when the plug is in the cell).

This species may be readily distinguished from all others found in the hive by the character of its mycelium. Many of the hyphae have a large proportion of their cells converted into chlamydospores; this is sometimes carried so far as to give the appearance of an oidium-hypha (Pl. LXXV, Fig. $2, b$ ). The remaining cells tend to lose their protoplasmic contents, so that the hyphae when mature break up readily (Fig. 2,a). Other hyphae are more or less devoid of spores, or only bear occasional lateral or intercalary ones (Pl. LXXV, Fig. $1, a$ ).

The hyphae are $2-6 \mu$ in diameter. As a rule, they assume their characteristic appearance when quite young (Pl. LXXV, Fig. 3, $a$, where chlamydospore is shown in course of formation on a young hypha).

The chlamydospores are of various forms (Fig. 3). In position they are terminal, lateral, or intercalary, or are borne on short lateral processes (Pl. LXXV, Figs. I, 2). Their dimensions vary from $4-5 \mu$ to $9.5 \times 7 \mu$ or even

Annals of Botany, Vol. XXVI. No. CIII. July, 1912.] 


\section{Betls. - A Bee-hive Fungus, Pericystis alvei, Gen. et Sp. Nov.}

larger ; $8-6 \times 7-5 \mu$ are average measurements. ${ }^{1} \quad$ The walls of these spores are thicker than those of the ordinary hyphal cell ; this, together with their frequently isolated position, is felt to justify the use of the term chlamydospore rather than that of oidium-cell, although they resemble the typical oidium-cell in their capacity for immediate germination.

If a comb on which Pericystis alvei is present be examined in the early spring, ${ }^{2}$ some cells will be found in which the fungus is no longer white, but grey. In May it is not unusual to find specimens of a dark slate-grey colour. This change is due to the formation of the cysts. These are subglobose or irregularly oval objects $20 \mu$ (occasionally less) to $40 \times 30 \mu$ (average about $30 \mu$ in diameter), ${ }^{3}$ and contain numerous spores. The cystwall is thin, smooth, and structureless, semi-transparent, and has a polished appearance when viewed by reflected direct sunlight. It is dark green in colour, appearing black by reflected light. Each cyst is borne on three to five short hyphal branches, also of a dark green colour. The general appearance of a culture with mature cysts is shown in Pl. LXXVI, Fig. 10.

The walls of the mature cyst and its supporting hyphae are not dissolved when placed in concentrated sulphuric acid on a slip, covered with a cover-glass, and heated till bubbles are expelled.

The cyst-spores are hyaline, spherical, and thick-walled (Pl. LXXV, Fig. 9) ; they are $3.7-4.7 \mu$ in diameter, average $4.3 \mu$. The number present in a cyst is variable, depending on the dimensions of the cyst. So far they have not been observed to germinate. Possibly they require a resting period, or conditions different from those which are favourable to the germination of the chlamydospores.

The cyst arises as a swelling or lateral projection on a hypha. This puts out one or two (rarely three) processes, which fuse with a neighbouring hypha, usually bending through a right angle to do so (Pl. LXXV, Figs. 4, 5). The young cyst now increases in size, and its contents assume a vacuolated appearance (Pl. LXXV, Fig. 6). The wall presently begins to acquire a brownish tint ; a culture at this stage is of a pale salmon or bone colour to the naked eye. The tint deepens, till finally the wall turns green ; it almost attains its mature depth of colour before the spores begin to be visible within the cyst (Pl. LXXV, Fig. 7).

The fusing hyphae become septate at an early stage. Inspection of stained material reveals that there are three septa; one at the junction with the cyst, and two others close together further along the hypha (Pl. LXXV, Fig. 7). The contents of the young cyst are highly granular, and the septa are in consequence frequently invisible in unstained material.

1 Measurements taken from honey-gelatine culture material.

${ }^{2}$ Possibly in mid-winter also. Grey specimens were plentiful on some material in January; but these combs were from hives where the bees had died, so that the conditions were not normal.

3 Measurements taken from honey-gelatine culture material. 
Betts.-A Bee-hive Fungus, Pericystis alvei, Gen. et Sp. Nov. 797

The green colour, in the mature cyst, extends as far as the third septum ; the fusing hyphae can therefore be easily distinguished from the hypha bearing the cyst, by the septum near their distal ends (Pl. LXXV, Figs. 7, 8).

When several cysts form on one hypha, their processes often all fuse with the same neighbouring hypha (Pl. LXXV, Fig. 5). It has not been ascertained that this is invariably the case, so that any deductions from it as to a possible differentiation of the hyphae would be premature.

The cyst is indehiscent; the spores are presumably set free by the breaking of the wall.

Pericystis alvei is not very easy to cultivate. It will germinate readily on most media, and produce mycelium and chlamydospores; but cysts, if formed at all, are usually empty. The only satisfactory medium was found to be honey-gelatine. ${ }^{1}$ On this the fungus developed normally and cysts containing spores were produced.

Cultures of the fungus have a distinctly alcoholic odour. Gelatine is liquefied, but slowly; the process is often one of softening rather than of liquefaction.

Some rough experiments were made to test the effect of different temperatures on the germination of the chlamydospores. The results indicate that :

(I) The chlamydospores will not germinate at $26^{\circ}-38^{\circ} \mathrm{C}$., but do so when transferred from this to $15^{\circ}-18^{\circ} \mathrm{C}$., so are not killed. The cultures were kept at $26^{\circ}-38^{\circ}$ for $13^{-16}$ days.

(2) They germinate at $15^{\circ}-18^{\circ} \mathrm{C}$. in $\mathrm{I}-5$ days.

(3) They germinate under outdoor conditions (mild winter weather) in about II days.

These facts are of interest in view of the probable life-history of this species. In the spring the bees clean out their combs, throwing the plugs of mouldy pollen out of the hive. Some of the spores will, however, be left in the hive, and will remain there during the summer. When the stock swarms, the bees of the swarm probably take with them some spores adhering to their bodies, and so transfer the fungus to the new colony. If this be so, we can see that the inability to germinate at high temperatures is of use to this species. The temperature of the bee-hive when the bees are active is $32^{\circ}-34^{\circ} \mathrm{C}$.; were the spores to germinate under these circumstances, the bees would remove the fungus from the combs as fast as it grew. In the winter, on the other hand, the temperature does not usually exceed I $2^{\circ}$ C. $;^{2}$ and the fungus is able to establish itself unmolested by the bees, which are hibernating in a cluster in the central part of the hive.

1 Diluted honey (three or four parts of water to one of honey), Ioo c.c.; gelatine (Gold Label), Io grm. The medium was usually left acid.

2 The consensus of opinion seems to peint to this as the temperature of the cluster when quiescent. The outer combs, where the fungus usually grows, are of course colder. 
798 Betts.-A Bee-hive Fungus, Pericystis alvei, Gen. et Sp. Nov.

Attempts to cultivate Pericystis alvei on bouillon, bee-pupa agar, \&c., were not very successful ; and there is no reason to suppose that this species is ever pathogenic in the bee. It is, in fact, present alike in healthy and in diseased stocks; if occasionally more plentiful in the latter, this is due to some secondary cause such as the weakness of the colony rather than to any direct connexion with disease.

As this fungus is undoubtedly a normal inmate of the healthy bee-hive, and is, so far as is known, confined to that habitat, I propose for it the name Pericystis alvei.

Pericystis, gen. nov. Hyphis repentibus vel suberectis, contextis, ramosis, septatis, multis cellulis in chlamydosporas se mutantibus, tandem saepe se dissolventibus. Chlamydosporis terminalibus lateralibus intercalariisque, subglobosis vel irregulariter ovalibus, membrana crassa, lēvi. Cystis subglobosis vel ovoidibus, tribus ad quinque ramis hyphalibus ferentibus, sporis numerosis repletis. Membrana cysti membranacea, simplice, lēvi, tandem fusca. Sporis hyalinis, sphericis, membrana crassa, lēvi.

$P$. alvei, sp. nov. Characteres ut supra. Mycelium album. Hyphis 2-6 6 (saepissime $5 \mu$ diam.). Chlamydosporis $9.5-4.5 \times 7-4.5 \mu$. Cystis $40-20 \times 30-20 \mu$; membrana cysti tandem atroviridi. Sporis $3 \cdot 7-4 \cdot 7 \mu$ (saepissime $4 \cdot 3 \mu$ diam.).

Hab. ad pollinem in favis Apis mellificae.

Pericystis, gen. nov. Hyphae creeping or suberect, interwoven, branched, septate, having many cells converted into chlamydospores, ultimately breaking up. Chlamydospores terminal, lateral and intercalary, subglobose or irregularly oval, thick-walled, smooth. Cysts subglobose or ovoid, borne on three to five hyphal branches, containing numerous spores. Cyst-wall membranaceous, structureless, smooth, ultimately dark-coloured. Spores hyaline, spherical, thick-walled, smooth.

$P$. alvei, sp. nov. Characters of the genus. Mycelium white. Hyphae 2-6 6 (average $5 \mu$ diam.). Chlamydospores $9.5-4.5 \times 7-4.5 \mu$. Cysts $40-20$ $\times 30-20 \mu$; cyst-wall ultimately dark green. Spores $3 \cdot 7-4 \cdot 7 \mu$ (average $4 \cdot 3 \mu$ diam.).

Hab. on pollen in the combs of the honey bee.

In conclusion, I wish to express my thanks to Miss A. Lorrain Smith for her kindness in giving me much helpful advice.

\section{Summary.}

A new fungus, Pericystis alvei, prevalent in bee-hives, is described, and its probable life-history discussed. 
Betts.-A Bee-hive Fungus, Pericystis alvei, Gen. et Sp. Nov. 799

\section{EXPLANATION OF PLATES LXXV AND LXXVI.}

Illustrating Miss Betts's paper on Pericystis alvei.

The magnification is uniform for Plate LXXV, and is approximately $\times 700$. The figures were drawn with the aid of a camera lucida from unstained material. All the specimens (with the exception of those figured in Plate LXXV, Fig. 2, $a$, and Plate LXXVI, Figs. II and I2) were taken from cultures on honey-gelatine.

\section{PLATE LXXV.}

Fig. I. Hyphae and chlamydospores from a young culture. $a$, hypha with few spores; $b$, spores on lateral processes.

Fig. 2. Hyphae and chlamydospores from an older culture. $a$, an old hypha, cells between spores have lost their contents; $b$, an oidium-hypha (from comb). hypha.

Fig. 3. Chlamydospores. a. spore germinating, and a chlamydospore forming in the resulting

Fig. 4. Young cyst ; early stage, before fusion.

Fig. 5. Two young cysts on one hypha, after fusion.

Fig. 6. Young cyst; shortly before wall changes colour.

Fig. 7. Cyst; wall has turned green, but spores not yet visible.

Fig. 8. Mature cyst.

Fig. 9. Cyst-spores.

\section{PLATE LXXVI.}

Fig. Io. Mycelium and cysts. $\times 50$.

Fig. Ir. $P$. alvei growing on pollen in comb.

Fig. 12. Pollen from cells, attacked by $P$. alvei, and converted into hard plugs

(Figs. II and $\mathbf{2} 2$ are slightly more than twice natural size.) 

Annats of Botany,

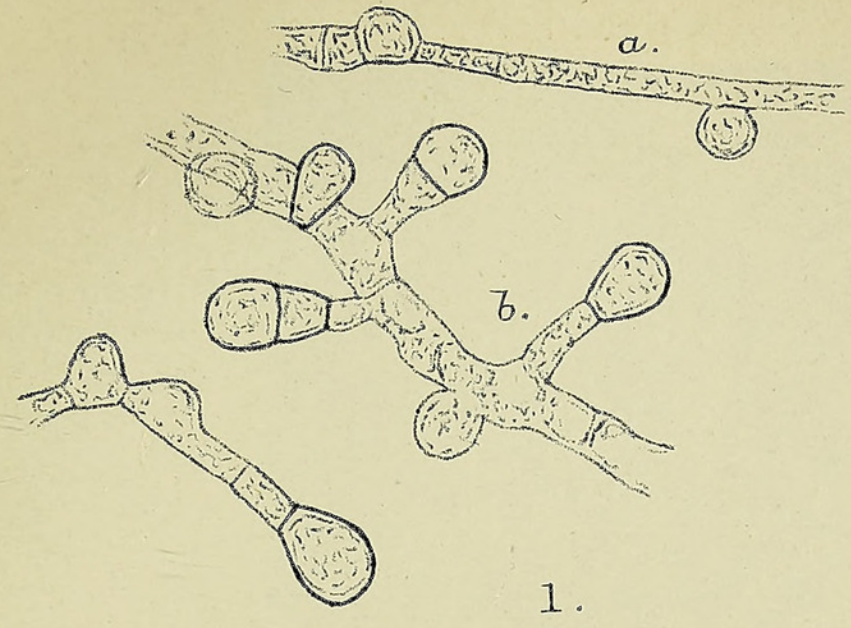

2.
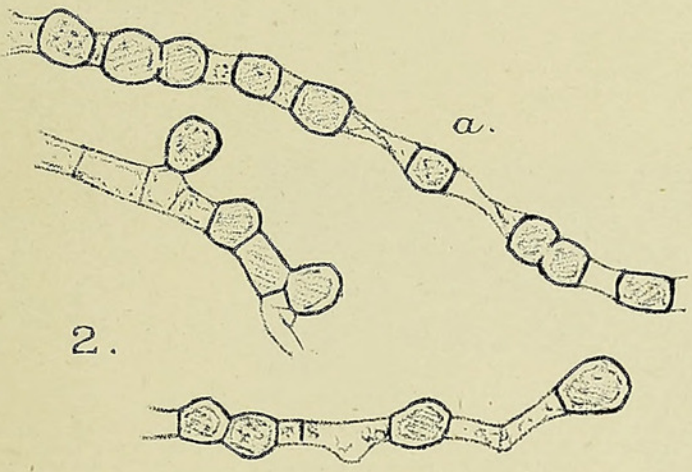

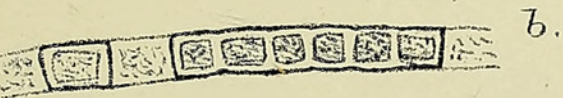
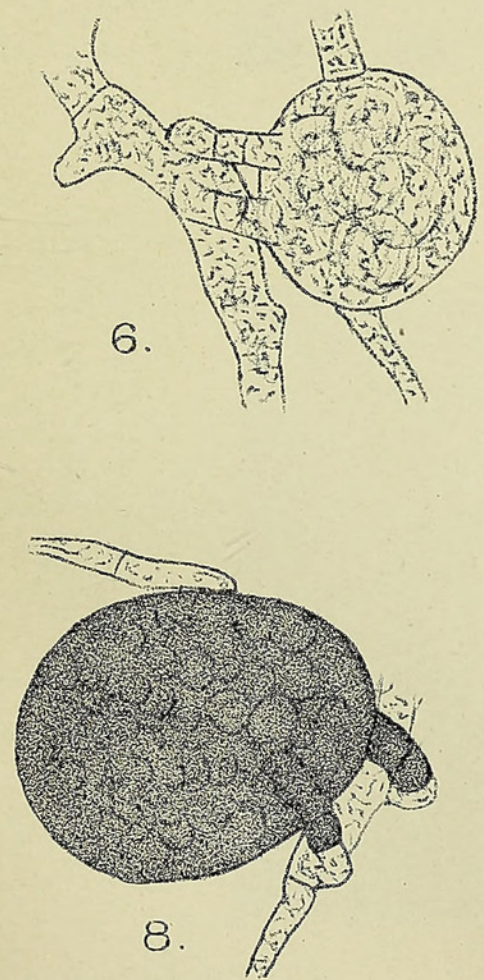

A.D.B. del.
Vol.XXVI, PZ.IXXV.

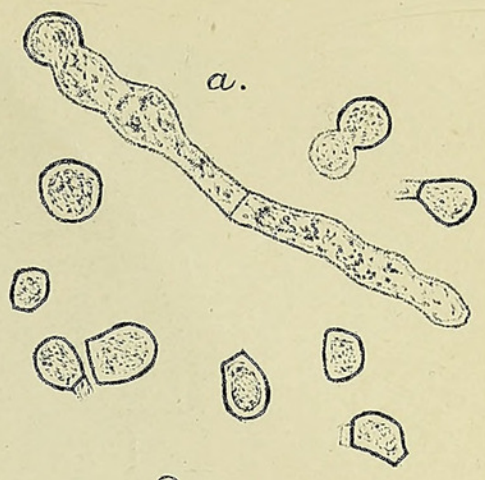

3.
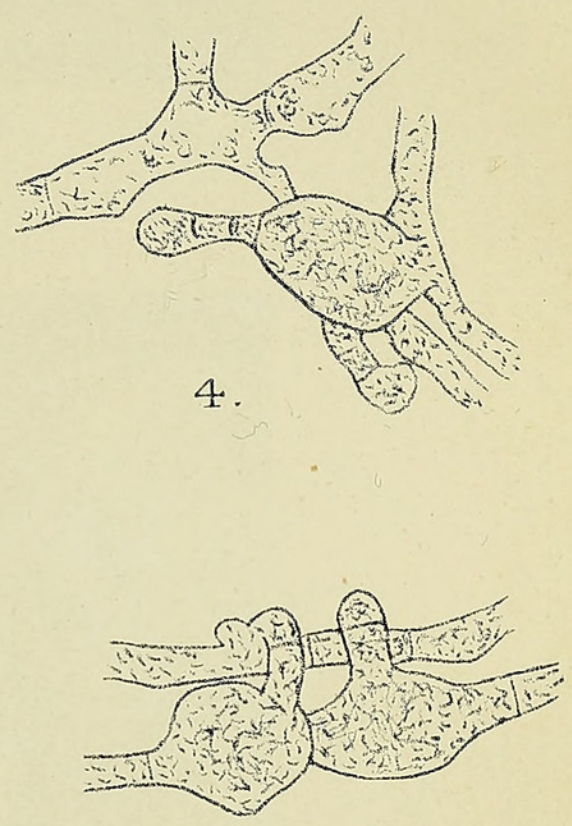

5.

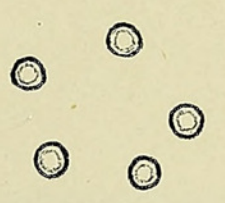

9.

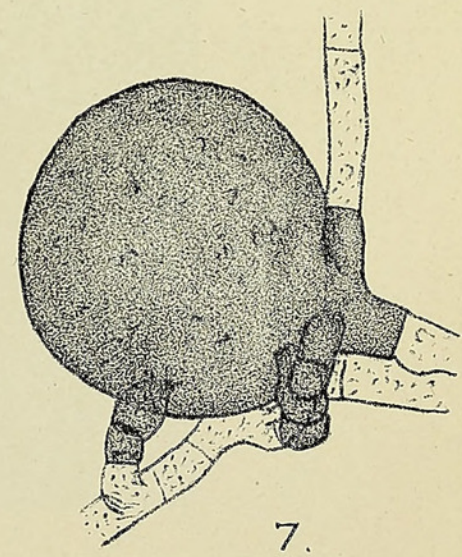

Huth lith et imp. 
Annals of Botany.

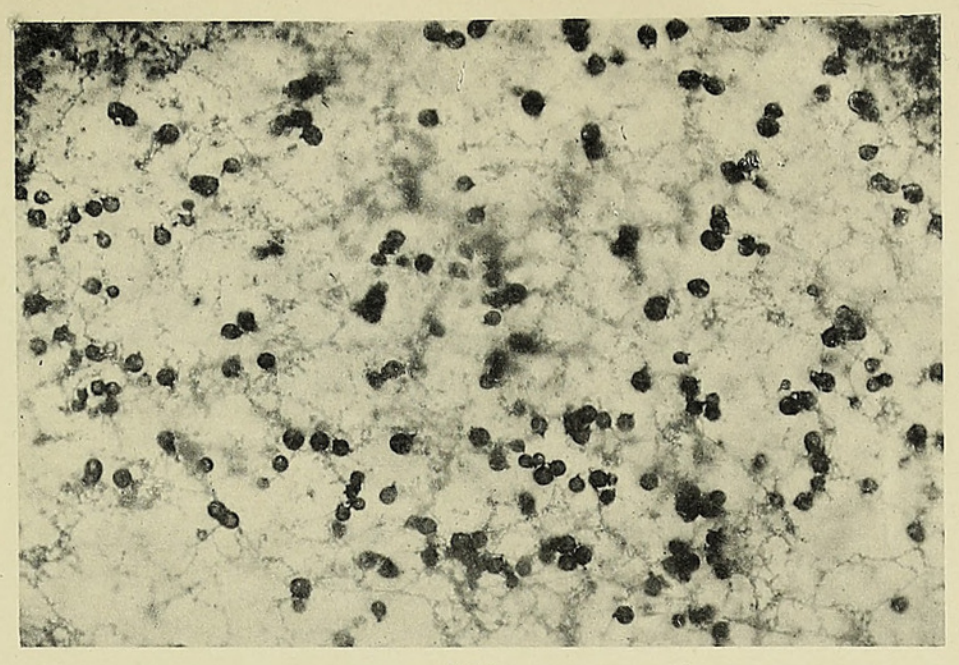

10.

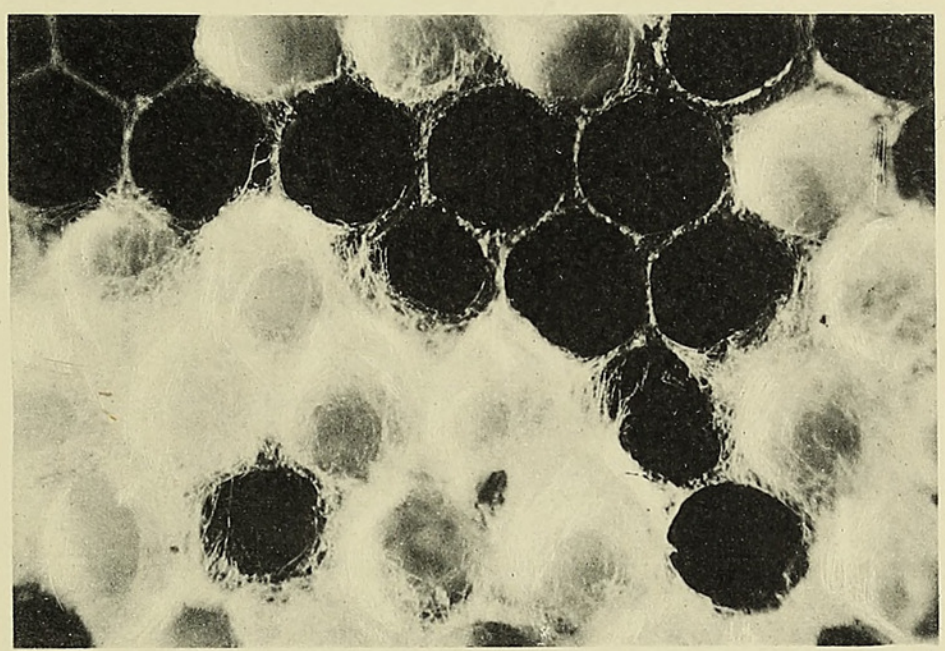

11.

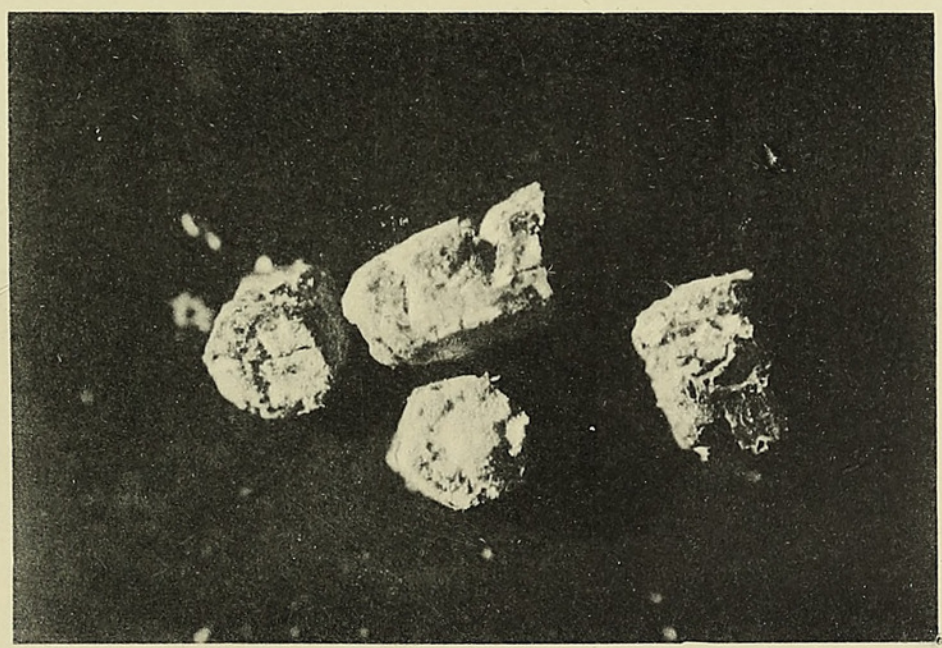

AD.B.phot.

12.

Huth, coll

BETTS PERICYSTIS. 


\section{$2 \mathrm{BHL}$ Biodiversity Heritage Library}

Betts, Annie Dorothy. 1912. "A bee-hive fungus, Pericystis alvei, gen. et sp. nov." Annals of botany 26, 795-800.

https://doi.org/10.1093/oxfordjournals.aob.a089417.

View This Item Online: https://www.biodiversitylibrary.org/item/236930

DOI: https://doi.org/10.1093/oxfordjournals.aob.a089417

Permalink: https://www.biodiversitylibrary.org/partpdf/319930

\section{Holding Institution}

Smithsonian Libraries

\section{Sponsored by}

Biodiversity Heritage Library

\section{Copyright \& Reuse}

Copyright Status: Not in copyright. The BHL knows of no copyright restrictions on this item.

This document was created from content at the Biodiversity Heritage Library, the world's largest open access digital library for biodiversity literature and archives. Visit BHL at https://www.biodiversitylibrary.org. 